ISCKMC 2020

International Scientific Congress «KNOWLEDGE, MAN AND CIVILIZATION»

\title{
DEVELOPMENT OF MEDICAL EDUCATION IN THE KHABAROVSK TERRITORY IN THE 1960S-1970S
}

\author{
Mikhail Alexandrovich Kovalchuk (a)*, Sergey Vasilyevich Bobyshev (b), \\ Nona Michailovna Platonova (c), Anna Valinurovna Akhmetova (d) \\ *Corresponding author
}

(a) Far Eastern State Transport University, 47, Serysheva str., Khabarovsk, Russia, unid@knastu.ru,

(b) Far Eastern State Transport University, 47, Serysheva str., Khabarovsk, Russia, history@festu.khv.ru,

(c) Far Eastern State Transport University, 47, Serysheva str., Khabarovsk, Russia, nonnaplaton@mail.ru,

(d) Komsomolsk-na-Amure State University, 27, Lenina str., Komsomolsk-na-Amure, Russia, srdsehp@knastu.ru

\begin{abstract}
The paper attempts to analyze the results of the activities of the Preparatory Department of the Peoples of the North in Khabarovsk State Medical Institute at the stage of its formation. One of the most challenging tasks faced by contemporaries is the reconstruction of the Soviet past. On the one hand, there is a temptation to cross out achievements by the Soviet people in the context of a general critical understanding of socialist modernization supported by newly opened documents, and new approaches in historical science. On the other hand, there is another danger - a dismissive look at the current state of society, and, in turn, idealization of the past, which is perceived as ideal. In our opinion, the relevance of any modern historical research is determined by the ability to avoid these extremes, which allows us to gain certain experience from the past, which we consider invaluable. The paper highlights the role of Khabarovsk State Medical Institute in training of highly qualified medical personnel for representatives of indigenous peoples of the North and the Far East. Particular attention is paid to the activities of the Preparatory Department of the Peoples of the North in Khabarovsk State Medical Institute. Emergence of new archival documents in scientific circulation allows us enhance our insight into the role of Khabarovsk State Medical Institute in training of medical personnel for representatives of indigenous peoples of the North and the Far East.
\end{abstract}




\section{Introduction}

One of the most challenging tasks faced by contemporaries is the reconstruction of the Soviet past. On the one hand, there is a temptation to cross out achievements by the Soviet people in the context of a general critical understanding of socialist modernization supported by newly opened documents, and new approaches in historical science. On the other hand, there is another danger - a dismissive look at the current state of society, and, in turn, idealization of the past, which is perceived as ideal. In our opinion, the relevance of any modern historical research is measured by the ability to avoid both extremes, which allows us to gain certain experience from the past, which we consider invaluable.

The history of the Preparatory Department has never been overlooked. These are mainly some of the publications in journals (Suleimanov, 2013) and newspapers (Boyko, 2009), and anniversary editions dedicated to the Far Eastern State Medical University (Molochny \& Boyko, 2005). These publications are mainly complementary in nature. Soviet publications certainly require careful rethinking. Along with new archival documents involved in the scientific circulation, this allows us to have a deeper insight into the role of Khabarovsk State Medical Institute in training of medical personnel for representatives of indigenous peoples of the North and the Far East (Akhmetova, 2017).

\section{Problem Statement}

Transformation of traditional societies of indigenous peoples in conditions of socialist modernization of the Far East is an integral part of the process of changing of a traditional way of life of indigenous peoples around the world (Alpyspaeva et al., 2019). In the XX century, the cultures of these peoples have experienced a large-scale impact of technological civilization. Its attack on traditional societies of autochthonous ethnic groups sharply raised the question of the path of their further development (Ebanda et al., 2019). The experience of the national policy in relation to small ethnic groups will be considered to study the patterns in the field of health protection of indigenous peoples, regional specificity of these processes in the Far Eastern region.

\section{Research Questions}

In 1949, the first admission of the peoples of the North was performed to the Preparatory Department opened in Khabarovsk State Medical Institute. It should be noted that some preparatory work preceded this event. Conspicuous is the fact that local health workers informed the relevant regional authorities about the situation with personnel in the northern regions of the region. Antonov, the head of Chukotka district health department reported in a note sent to the health department in the Khabarovsk Territory that in 1947, only 6 out of 15 doctors who were sent through Vladivostok to Chukotka district health department, came to the district center Anadyr. Some of the rest stayed at the Magadan regional health department. Three young women graduated from the medical school married on the way and were released from compulsory working. The rest got a job in other places and probably worked not by profession. Eight female doctors arrived in the North in 1948-1949 for family reasons either left their destination or worked in Chukotka on a limited basis (they got married and gave birth to a child) (SAKhT). 
Antonov is right to consider the main reason for unsuccessful personnel policy in the fact that they typically send graduates of Soviet universities, mainly KSMI, who have neither professional nor life experience of living in the North. The representatives of the medical institute could be also convinced of the fairness of what Antonov wrote. In summer 1948, a medico-parasitological expedition worked in Chukotka under the leadership of A.V. Maslov, associate professor from KSMI, Candidate of Biological Sciences. In the report on the expedition results, he stated that in a number of settlements medical posts are listed only on paper, since there are no medical workers (SAKhT).

This seems to suggest that it is necessary to train doctors from local residents who know the North and can return to their small homeland after graduation with no fear of everyday challenges. The best match for this role was young representatives of indigenous peoples of the North and the Far East. However, the annual reports of Khabarovsk Medical Institute for 1947/1948-1950/1951 academic years indicate that not a single representative of indigenous peoples of the Far East and Siberia could be found among the students of the institute. The report for the 1951/1952 academic year only mentioned the fact of admission to the institute of one Kamchadal. Russians (221 people) ranked first among freshmen students (221 people), then Jews (13 people) and Ukrainians (10 people), and one representative from other peoples of the USSR, including Estonians, Lithuanians, Tatars, etc. (SAKhT). The documents also record the fact that applicants from remote areas of the Khabarovsk Territory could not arrive on time for entrance exams (SAKhT). In addition to the inaccessibility of remote areas, there was a cultural and psychological barrier for representatives of indigenous peoples for admission to a university, which could not be overcome even in the 1960 s, i.e. after two decades.

\section{Purpose of the Study}

The purpose of the study is to use modern methodology in order to analyze the activities of the Soviet government in the field of health care for the natives of the Far East in the 1950s-1960s.

\section{Research Methods}

The social history of medicine is an up-to-date trend in modern humanities. Its representatives study medicine within the framework of the historical development of society. Medicalization is the most important category of this theory. The founders of this concept believed that state intervention in the lives of citizens would be much more effective if they shared the idea of the benefits of this intervention aimed at ensuring the health of the population (Nye, 2003). Similar processes were typical of the period when the health care system was formed in national regions of the Far East. Members of medical teams and medical expeditions performed not only their therapeutic functions, but also carried out educational, educational activities on the new way of life with the natives from remote regions, and often campaigned for Soviet power. Medicalization can be considered the most important mechanism for development of small ethnic groups in the era of Soviet modernization, which exerted a disciplining effect on the local population in many respects and under no duress involved it in the sphere of influence of the Soviet state. 


\section{Findings}

On December 12, 1948, the Ministry of Higher Education of the USSR, by order On Training of Personnel from among the Peoples of the Far North, recommended that the Ministry of Health of the RSFSR open a Preparatory Department in Medical Institute in Khabarovsk and provide it with curricula, programs, textbooks, and necessary equipment and teachers. By order of the Minister of Health of the RSFSR of December 30, 1948, the Preparatory Department was opened in the institute, which that provided three years of study for young people - representatives of indigenous peoples of the North and the Far East with a seven-year education (Chikin \& Cheknev, 1978). At the early stage of the Preparatory Department work, the institute had to face the problem - accommodation for an additional contingent of young nonresident students due to the lack of places in the dormitory. In October 1948, S.K. Nechepaev, a new rector of the medical institute, wrote a memo addressed to the head of the school department of the regional committee of the All-Union Communist Party of Bolsheviks that we have to put two people on one bed this year. There are at least 100 double beds left.' The situation was aggravated by the fact that the institute had to transfer from 5-year to 6-year education.

In this regard, the rector sent a letter to the Chairman of the Council of Ministers of the RSFSR with a request to allocate funds for construction of a new dormitory for medical students. The problem was partially solved in 1952, when a dormitory for students with 600 places (Karl Marx str., 60) was put into operation and populated. Finally, the issue of classrooms and accommodation for students in a dormitory was solved in the first half of the 1960s, when a magnificent building of the main building of the medical institute and another dormitory were built (SAKhT).

Further on, the management of the institute abandoned the idea of the preparatory courses that provided a full range of school subjects taught in senior grades at the institute. At the institute, only a boarding school was left for students of grades 8-10 from among the representatives of indigenous peoples of Siberia and the Far East taught in an ordinary secondary school in Khabarovsk (Boyko, 2009).

In 1952, the graduates of the first admission of the preparatory department became students of KSMI at the department of the peoples of the North. After six years of study, they received their medical degrees. Out of 25 students, only 13 received diplomas of doctors, that is a little bit more than a half (52\%). Despite the fact that the state covered all the expenses for the maintenance of northerners, this result was incompatible with the market approach to education. Moreover, none of those who received their diplomas could even apply for it, because almost all of them came from the families of workers and collective farmers, some were orphans by the time of placement of graduates. All of them were 'children of war', their childhood fell on the hard times of war. The average age of graduates was 27.2 years. Some specialists graduated from the institute at the age of over 30. Their perseverance and desire to get a profession was obvious. However, the problem of adaptation of indigenous peoples of the North to new conditions cannot be neglected. The documents reflect the reality of the Soviet era - all the first doctors were northerners who studied at the Department of the Peoples of the North, even those who had a city residence permit.

The records of the pedagogical councils of the Preparatory Department over the period of 1958-1959 stored in the files of the KSMI archives state a low level of school education of students, especially in object-oriented subjects (physics, mathematics and chemistry), and the enormous efforts of teachers to eliminate this problem. Often, students did not have time to master the material within the 
allotted time, and teachers had to conduct additional classes for those lagged behind. This required wellcoordinated and selfless work of the teaching staff and the head of the department A.F. Shamray, an experienced and outstanding teacher (SAKhT). Apparently, he fulfilled his duties on a voluntary basis, since his primary place of employment was the Department of Biology, KSMI. A.F. Shamray devoted himself entirely to scientific and pedagogical work and delegated his authority to A.I. Arkush. The first subject teachers were: E.A. Guseva (Russian language and literature), M.L. Lukasheva (chemistry), Yu.M. Borovikov (physics, mathematics), A.R. Karskaya (history and social science), and A.F. Shamray (biology). In the 1960s, Nadezhda Trofimovna Ganzhina (Gavryushchenko) became the head of the department and worked in this position until 1987. Her colleagues noted that she '... treated her pupils with motherly care and understanding'. Another circumstance must also be noted. In the second half of the 1960s, when teaching of academic disciplines shifted to a comprehensive school, the pedagogical staff of the Preparatory Department was recruited on a vacant basis: one staff unit for the head and two units for the educators. It was during these years that the teaching staff became apparent, which favorably affected educational work.

Despite all the measures taken, it was impossible to achieve stability in training of highly qualified personnel in the late 1950s. In 1959, only 3 people received medical diplomas, and the next year the number was even less -2 . Nevertheless, since the beginning of the 1960s, a constant increase in the representatives of indigenous peoples of the North among the KSMI graduates, and thus in the period of 1958-1970 their total number was 133 people. At the same time, the maximum number of graduates-northerners fell on 1967 and amounted to 20 people, and the average annual number for the 1960s was 11-12 people (SAKhT).

The internal statistics of students at the Preparatory Department and students-northerners, who were fully supported by the state (Department of the Peoples of the North), makes it possible to better understand the problems of their preparation at the university as a whole. The data for 1967 are especially evident in this regard. A total of 101 students-northerners were to study at six courses of the medical and pediatric faculties. However, 16 people were deleted from the general list in the course of its compilation, with notes in the margins: 'dropped out', 'expelled'. Probably, part of these students did not start their studies on September 1, and others were expelled during the semester. When registering students, the year of their admission to the university was noted. These indirect data allow identification of students who, for one reason or another, took a gap year. It could be family circumstances, illness, but most often these circumstances covered up problems with studies. The share of such 'problem' students in all six courses exceeded a quarter of their total number. The majority of them took a gap year in the first year of study (31.2 \%). On average 21-22 people a year graduated from the preparatory department, and 13 people became students in 1966 and in 1969, which indicates that 8-9(!) students annually did not become students. In addition, there were those who took a gap year. No doubt, this could not at all be evidence of the high quality of training of specialists from among the representatives of indigenous peoples of the North and the Far East.

The overall level of training of students who graduated from the Preparatory Department and entered the university left much to be desired. It should be noted that they studied for three, and then for two years in the city but not in a rural school, where the level of teaching was lower for objective reasons. Therefore, the main reason for dropping out is the inability of individual students from the North to adapt to new 
conditions. This was evident after the completion of the Preparatory Department and in the first years of study at the university, when the 'motherly' care of educators ceased. These three factors were predominant:

- adaptation to the foreign environment;

- adaptation to city life;

- adaptation to patterns of life and thought.

The Nanais and Ulchi, the peoples of the Amur, settled in a relatively urbanized region that includes Khabarovsk, Komsomolsk, and Nikolaevsk. Among the first graduates, there were two people whose parents, at the time of graduation the university, lived in Khabarovsk (O.G. Deichuli) and in Komsomolsk (N.G. Uda). The entire vast Far North-East had only two relatively large cities - Magadan and Petropavlovsk, and the Uelen settlement, although the level of urbanization in the Far North-East was not lower than across the country. The indigenous peoples of this subregion - the Chukchi, Evenks, Koryaks, and Itelmens - led a settled way of life; nevertheless, they retained the main branch of the economy reindeer husbandry, which was impossible without long nomadic camps, in which children also took part in summer (SAKhT).

Many former students of the Preparatory Department, the KSMI graduates, have shown themselves as highly qualified professionals, politicians, and cultural workers. O.D. Tumnattuvge, a graduate of the first enrollment, worked in Anadyr and headed the Department of the Peoples of the North of the administration of the Chukotka Autonomous Okrug. She was awarded the title of Honored Doctor of the RSFSR and the medal For Labor Valour. L.P. Kile, pediatrician, chief physician of the Naihinskiy district hospital in Nanai region, was awarded the title of Honored Doctor of the Russian Federation. M.I. Ettyryntina, who graduated from KSMI in 1964, became the chief physician of the tuberculosis dispensary in Anadyr. She was twice elected as a deputy of the Supreme Soviet of the RSFSR, was elected to the Federation Council of the Federal Assembly of the Russian Federation and was the secretary of the Federation Council Committee for the Commonwealth of Independent States. S.A. Eliseikin, a 1969 graduate, was the chief doctor of the regional maternity hospital in Magadan, was a deputy of the Supreme Soviet of the RSFSR, and in the 2000s he represented Magadan region in the State Duma of the Russian Federation. M.B. Aktanko, a 1966 graduate, pediatrician of the district hospital in the Troitskoe village, Nanaisky district, in 1981 was elected as a delegate to the XXVI Congress of the CPSU. A graduate of the preparatory department, KSMI, physician L.I. Abryutina defended her thesis for the degree of candidate of sociological sciences and worked in the Moscow government. In Soviet times, over the years of work of the department of the peoples of the North, more than 500 specialists with higher medical education graduated from KSMI. Similar departments at Krasnoyarsk and Omsk medical institutes ceased to exist in the post-perestroika period, however, in Khabarovsk, despite serious financial problems, it still holds up well today and significantly contributes to the development of the health care system of indigenous peoples of the Far North and the Far East (Bobyshev \& Akhmetova, 2015).

\section{Conclusion}

The considered problems of the development of higher medical education among indigenous peoples of Siberia and the Far East cannot bring to naught the enormous achievements in this area. Hundreds of northerners have received diplomas of doctors and pharmacists. Much was written about this in Soviet 
times. We can now look more critically at these achievements since a long period of time has passed to allow a deeper look at the existing problems. However, it was in the 1960s when the number of indigenous local peoples of the Far East was observed to increase, thus eliminating the problem of their extinction. No doubt, the system of training highly qualified medical personnel created at Khabarovsk State Medical Institute (now the Far Eastern State Medical University) significantly contributed to the problem solution. The system was based on two principles: firstly, preferential, out-of-competition procedure for admission to the institute, and, secondly, full or partial financial support for students of the Preparatory Department and students of the institute.

\section{Acknowledgments}

The study was funded by RFBR, project number 20-09-00023.

\section{References}

Akhmetova, A. V. (2017). Transformation of ethnocultural development of indigenous peoples in the conditions of socialist modernization of the Far East in 1920-1970s: problems of historiography. Contribut. to Econ., 9783319454610, 553-558.

Alpyspaeva, G. A., Zhuman, G., \& Bagdatova, S. A. (2019). Discussions on the christianization of the Kazakhs of Turkestan region (second half of the 19th - early 20th centuries). Bylye gody, 52(2), 655-667.

Bobyshev, S. V., \& Akhmetova, A. V. (2015). Modernization of ethnocultural processes in the national areas of the Far East (1920s - 1930s years). Bylye gody, 3(3), 766-774.

Boyko, T. (2009). Medics travel to the North. Pacific Star. https://toz.su/archive1/?ELEMENT_ID=91510 Chikin, S. Ya., \& Cheknev, B. M. (1978). Health protection of the peoples of the North. Medicine.

Ebanda, R. O., Michieka, R. W., \& Otieno, D. J. (2019). A cultural paradigm shift in Central Africa: Sociocultural determinants and cultural dimensions. Int. J. of Interdisciplinary Soc. and Community Stud., 14(1), 83-99.

Molochny, V. P., \& Boyko, T. A. (2005). Anniversary book: the 75th Anniversary to the Far Eastern State University. Publ. House of the Far Eastern State Medical Univer.

Nye, R. A. (2003). The Evolution of the Concept of Medicalization in the Late Twentieth Century. J. of History of the Behavioral Sci., 39(2), 117.

Suleimanov, S. S. (2013). Preparatory department of the peoples of the North. Assembly of Peoples of Khabarovsk Territory, 33, 26-27. 